\title{
Research
}

\section{How does Diversity Matter? The Case of Brazilian River Basin Councils}

\author{
$\underline{\text { Andrew Reid Bell }}^{1}, \underline{\text { Nathan Lee Engle }}^{2}$, and Maria Carmen Lemos ${ }^{2}$
}

\begin{abstract}
Diversity as a concept has often been perceived as a positive system attribute to pursue and protect. However, in some social settings, the way different kinds of diversity shape outcomes can vary significantly. Diversity of ideas and individuals sometimes can lead to disagreement and conflict, which in turn can lead to both positive and negative outcomes. In this study, we examine identity diversity, i.e., age, income, education, worldviews, etc., within the context of Brazilian water governance. We find that within the basins studied in this project, first, the more diversity in organizations and the sectors represented on the council, the more council members participate in council activities, perceive decision making to be democratic, and perceive technical information to facilitate decision making. Second, diversity in what members perceive to be the most pressing problems facing the basin and also diversity in worldviews often correlate negatively with some measures of participation and the perceived importance of technical knowledge. Third, diversity in the level of experience with water issues negatively correlates with some measures of participation and perceived democratic decision making. Fourth, diversity in the perception of the most important problem facing the basin leads to poorer outcomes in the council. Our work provides an argument for supporting broad sectoral representation of interests within deliberative decision making bodies; however, it also illustrates that it is critical for these bodies to explore ways to resolve basic disagreements about the most important problems that need to be addressed and where their collective efforts should be focused.
\end{abstract}

Key Words: Brazil; identity diversity; integrated water resources management

\section{INTRODUCTION}

Diversity as a concept has often been perceived as a positive attribute to pursue and protect. In the biological, ecological, and complexity sciences it is tied to ideas of richness, resilience, and robustness, all good things to have (Peterson et al. 1998, Allen et al. 2005). Socially and culturally it has also come to be something to be celebrated and created. However, in some cases, diversity may lead to undesirable outcomes. For example, in the context of participatory decision making councils, the range of heterogeneity of interests and attributes represented on the council sometimes can lead to disagreement and conflict, which in turn can lead to less participation and lower engagement in the process. On the other hand, such diversity of representation may facilitate individuals to be more engaged in the decision making process, potentially leading to improved environmental outcomes, learning and trust, and ultimately consensus building. In this sense, understanding how and where different aspects of diversity can be beneficial or detrimental deserves closer attention. In this study, we examine diversity within the context of Brazilian water governance. We focus particularly on aspects of identity diversity such as age, income, education, worldviews, and the sector represented on the council, and how they relate to different aspects of decision making within decentralized water management.

Brazil's water reform has sought to decentralize governance by creating a number of institutions and organizations at the river basin level, which in principle, should not only devolve decision making to its most appropriate jurisdiction but also integrate the many goals of water management, e.g., economic, social, environmental, cultural, etc. One type of these organizations are river basin councils, i.e., committees and consortia, whose mandates include (1) the design and approval of river basin 
plans; (2) the establishment of water quality goals; (3) the creation and implementation of water permits and charging mechanisms, including the establishment of priorities of how to spend the revenues; and (4) and the arbitration over conflicts (Lemos et al. 2010). Consortia differ from committees in that they are not legally established; although they share the same range of responsibilities as committees, they have lower capacity for enforcement. To date, over 150 of these councils have been created all over Brazil with different levels of success (Abers and Dino 2005). The Brazilian case offers a unique opportunity to observe how different aspects of diversity shape processes within deliberative councils. Each individual river basin has been created to reconcile diverse interests and needs within the basin. However, the way in which councils are constituted, i.e., the level of diversity among council members, can vary greatly between basins. One reason for such interbasin diversity is that within Brazil's federalized management model, states apply rules for management and representation differently, leading to variability between cases with respect to the sets of goals and priorities represented on the councils. Another reason is that the different levels in environmental stresses and economic development across Brazil lead to a diverse set of problems faced within each of the councils. In this study, rather than focusing on the differences between councils, we focus on diversity within river basin councils and how it relates to their decision making process.

We build upon previous empirical research to explore a set of assumptions about the role of diversity in decentralized decision making, drawing from the literatures of organizational theory and collaborative management, and making use of data from the Watermark Project, which interviewed 626 river basin council members in 18 basins across Brazil. Because of the nature and limitations of the data available, we focus our study on the links between council member diversity and their perceptions in relation to several aspects of the decision making process. In doing so, we hope to provide a more detailed understanding of how stakeholder diversity shapes processes within river basin councils and to generate new avenues of inquiry on the subject. In turn, by looking more closely at the influence of diversity on council's processes, our study results will hopefully be useful in designing and evaluating not only more effective river basin councils but also other kinds of decentralized deliberative organizations.

\section{How does diversity matter?}

A number of researchers in organizational theory have investigated the impacts that diversity, defined here as the range and heterogeneity of interests and attributes represented within decentralized management organizations, has on the function of management groups and the satisfaction of their members. A common characterization of diversity is distinguishing among observable characteristics and attributes, e.g., age, gender, sector of employment, etc., and unobservable characteristics, e.g., opinions, attitudes, and skill sets (Milliken and Martins 1996). The findings of such research are mixed, however. In their widely cited review, Milliken and Martins (1996) found that diversity in observable attributes can have negative consequences on the satisfaction that members of a group feel, reflecting a tendency for people to be more comfortable around those who are similar to them, although this negative influence tends to fade the longer the group is together. On the other hand, a number of cognitive benefits, i.e., the ability of a group to function and make decisions, are associated with both observable and unobservable aspects of diversity. Recent work by Page (2007) makes significant contributions to this literature by theorizing that an individual's characteristics, observable and unobservable, shape and reflect what he calls their instrumental and fundamental preferences, which in turn make different contributions to the functioning of decision making bodies such as stakeholder councils. As Page defines them, an individual's instrumental preferences are the preferred tools or approaches one uses to reach a particular goal, whereas an individual's fundamental preferences are the goals he or she holds as most important. Page suggests that the conflict brought about by diversity in instrumental preferences, i.e., different problem solving approaches, can lead to better decisions and more robust organizations, but that the conflict arising from diversity in fundamental preferences, i.e., different goals and beliefs, can sometimes be insurmountable, leading to outcomes for organizations that are mixed at best.

Diversity also plays a prominent role in studies of decentralization and collaborative management. Efforts to integrate water resources management and decentralize responsibilities to lower scales of decision making have been around for decades (Medema et al. 2008) and are generally part of a broader paradigm shift in the management and governance of water (Gleick 2000). In theory, 
among other benefits, a decentralized regime can be more democratic by increasing participation and representation of different stakeholder interests (Brannstrom et al. 2004, Lemos and Agrawal 2006, Abers et al. 2009). Moreover, the deliberative process promoted by decentralization can lead to trust-building, better production and use of knowledge, social learning, collective identity formation, and ultimately a more effective, efficient, and equitable resolution of water resource conflicts (Lubell 2005, Abers 2007, Lemos et al. 2010). However, the goals of decentralization in water management are not always achieved and, more importantly, in some cases, they may be in conflict. For example, in a comparison of water decentralization programs in Mexico and South Africa, Wester et al. (2003) found that more inclusion may slow down implementation of decentralization despite potentially leading to better outcomes in terms of participation. In Brazil's sweeping decentralization reform, the use of technical knowledge is often at odds with democracy and equity within river basin committees decision making processes (Lemos 2008, Lemos et al. 2010).

The decentralization and collaborative management literature also identifies diversity as a prerequisite for both effectiveness and legitimacy of governance. For example, Koontz and Johnson (2004) argue that the breadth of stakeholder participation is an important variable for determining certain watershed accomplishments, e.g., education and outreach, networking, policy changes, land acquisition, and research. In this case, broader inclusion of a diversity of interests, i.e., sectors, in watershed groups in the United States led to better measures on those outcomes, perhaps because of the ability to draw from various expertise to address the problem. Others, such as Abers (2007) show that a diverse representation of interests and pluralism in watershed management bodies is procedurally important in that it is more likely to bring attention to the most pressing issues, and decisions or agreements are more likely to elicit acceptance from the watershed's citizens (Focht and Trachtenberg 2005). Diversity can also positively influence the use of technical knowledge (Lemos et al. 2010) and expand the scope of the problems being considered by governance organizations.

However, the role of diversity within the context of water governance has received relatively little attention. Although diversity can be characterized in many different ways, the decentralization and collaborative management literature primarily defines diversity as the range of sectors of society or organizations represented within water governance (see for example Leach 2004). We argue that other aspects of diversity can play a critical role in the way decentralized governance works, especially considering the quality of the 'process,' e.g., perception of democratization, overall stakeholders' satisfaction, etc., rather than just the 'product' outcomes, e.g., policies, research and reports, etc., that have dominated these earlier research efforts. Stakeholder identities, i.e., who they are, their demographics, worldviews, and what they perceive to be the most important problems to solve, reflect diverse preferences, toolkits, and approaches to problem solving, and also shape representation and participation.

The principle of diversity is at the heart of the Brazilian water reform to the extent that broad stakeholder participation and representation have framed the new model of water resources management. Although mainly inspired by the Dublin principles, in practice, this model has been critically shaped by the federal character of the Brazilian state and by the organization of local water interests and politics. For example, although the Brazilian water legislation procedurally guarantees diversity by mandating tripartite representation, i.e., state, users, and civil society, within river basin councils, the actual representation of interests differs greatly across these councils. One reason is that the definition of the three main categories may vary considerably from council to council, e.g., who is a user or who can act as a representative of civil society, which in turn may result in overlapping between categories. Another reason is that there are no firm rules and little oversight regarding individuals switching from one category to another. For example, a water company engineer, who starts as a representative of the state, can reinvent him or herself as a representative of civil society by securing an appointment from a professional association or NGO (Kumler and Lemos 2008). A large public sewage utility can define itself both as a user and as a part of the state. In these cases, in principle, some sectors can be overrepresented while others may be shortchanged. In the case that interests conflict with each other, representatives may have to face tough choices.

By looking more closely at the influence of diversity on perceptions of council processes, our research 
results will help to identify potential barriers to, and promote factors for, successful watershed management. Beyond simply thinking of representation as a set of stakeholder interests, this study aims to reframe the issue of diversity in council makeup in terms of the different aspects of identity they bring to the decision making environment, and link these characteristics of basin council diversity to members' perceptions of the councils' decision making process.

\section{INVESTIGATING DIVERSITY IN BRAZIL'S WATER REFORM}

In the present work, we used data from the Watermark Survey carried out in 2004. The survey interviewed 626 members of 18 different river basin councils, i.e., 14 committees and 4 consortia, across Brazil. The sample was selected by stratifying existing river basin councils according to region, main water-related issue, type of basin, i.e., urban, rural, or coastal, and basin size; preference in selection within strata was given to basins that had previously been studied by the Watermark Project. We used a set of questions from the survey of basin council members as proxies for a number of attributes of identity and then used these questions to generate measurements of diversity at the level of basin council. We used a second set of questions from the same survey as measures for the levels of satisfaction and performance in the council (Fig. 1). We then correlated these process measures with our measures of diversity and illustrate our findings with in-depth, case study secondary data from our own research and from the published literature focusing on Brazil's water reform where available.

We chose as dependent variables and proxies for the perception of council processes all questions in the survey reflecting (1) the reported use of technical information in council decision making (TI); (2) the perceived level of democratic decision making made by the council (DD); and (3) the reported participation in council activities (PC). We have previously identified the use of technical information as an important process within the decision making process in decentralized water basins that critically shapes members' perceptions of overall efficacy (Lemos et al. 2010), while perception of democratic decision making and level of participation have been found to tie into concepts like satisfaction that Milliken and Martins refer to as 'affective reactions' (Milliken and Martins 1996).

As proxies for the independent variables, we selected all questions in the survey that revealed (1) unobservable 'worldview' characteristics (WV), such as attitudes about the role of humans in the environment, or the balance of rights between government and private property owners; (2) perception of the major problems $(\mathrm{P})$ affecting the basin; (3) the sector (S) represented on the council; and (4) a mix of demographic characteristics (D), such as age, gender, experience, and income.

We aggregated individual responses for the proxies to the basin level in one of four ways, i.e., mean, proportion, standard deviation, and statistical entropy, to give a final $n$ of 18 data points, with the basin as the unit of analysis. We measured the level of a response, measured in all but one of the dependent variable proxies, by the mean, for cardinal responses like age, income, or numerical Likert scales, and by proportion, for nominal responses, like the proportion of council members answering ' $c$ ' to a particular question. We measured the diversity of a response, measured for all independent variable proxies and for one dependent variable proxy, by the standard deviation, for cardinal responses, and the statistical entropy, for nominal responses. Ordinal responses in the survey were transformed to cardinal responses by assuming their values to be evenly spaced between 0 and 1 . Thus, for example, the set ['often,' 'sometimes,' 'rarely,' 'never'] becomes [1, 0.66, 0.33, 0]. Transforming the data makes it more amenable to analysis, revealing information that might be lost, particularly in our data where there are usually a small number of response options, by using the median (Wright and Linacre 1989, Velleman and Wilkinson 1993). We looked for correlations among the different independent and dependent variable proxies, with significant correlations identified as those for which the p-value of the Pearson correlation coefficient was less than 0.1 .

The complete list of questions used to develop the proxies, as well as the way in which the responses were coded, is included as Appendix 1; this appendix may be used as a helpful guide in interpreting the study results that are shown in Figure 2, and that are summarized in Appendix 2. 
Fig. 1. A subset of outcomes of the deliberative process in basin councils.

Diversity in: $\quad$ shapes perceived:

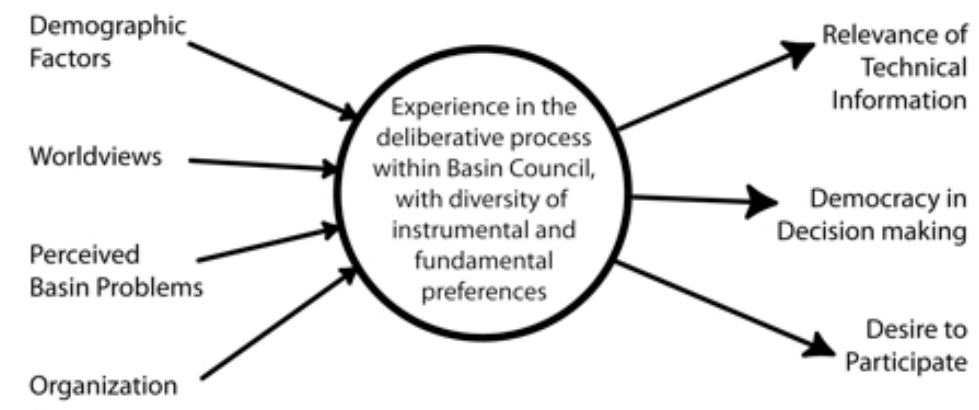

A complete description of the mathematical development of the four measures described above is included as Appendix 3 to this study.

\section{UNDERSTANDING THE ROLE OF DIVERSITY IN RIVER BASIN COUNCILS}

In the matrix depicted in Figure 2, the dependent variable proxies are listed along the y-axis, and the independents along the $\mathrm{x}$-axis, so that row $i$ shows the correlations that the independent variable proxies have with dependent variable proxy $i$. To keep the data legible while still providing explanatory power, proxies are given a short name that represents the question asked of the respondent. The reader is encouraged to refer to Appendix 1, where we provide a complete list of questions and the means by which they were coded. Correlations significant at $\mathrm{a}=0.1$ are shown as grey squares for positive correlations or black squares for negative correlations; white indicates a lack of significant correlation at $\mathrm{a}=0.1$. The full set of correlation coefficients and their $p$ values are found in Appendix 3.

In the following sections we organize the results of our analysis by independent variables, and discuss the roles these aspects of council diversity appear to play to the members' perception of the way the councils work.

\section{Diversity in basin problems}

Most significantly, diversity in what members perceive as the most pressing problems facing the basin (P1 and P2) correlates negatively with several aspects of participation and the use of technical knowledge. The implication of these results, that disagreement about what the focus of committee efforts should be leads to unproductive and unresolvable conflict, creating negative interpretations of the decision making experience by members of the council, has intuitive appeal. It is a result clearly visible in the Alto Tietê Basin case, a densely populated basin providing for irrigated agriculture, industry, and metropolitan São Paulo. The main committee for the basin has been held at an impasse over disagreements related to water pricing and has faded in importance; the complexity of such an intensely urbanized and industrialized region, reflecting a diversity of goals and perceived problems, has demanded management at smaller scales and the creation of five basin subcommittees, which focus on local issues and have been more dynamic and effective in their activities (FormigaJohnsson and Kemper 2005a). In other cases, effectiveness brought about by the dominance of particular agendas and the focus on fewer issues can come at the expense of broader relevance and legitimacy. In the Baixo Jaguaribe-Banabuiú Basin, the emphasis placed on managing water supply and allocation by the state water management company has meant that issues of local importance, i.e., water 
Fig. 2. Table of correlations among independent variables - diversity in observable and unobservable attributes of identity at the level of basin council - and dependent variables - outcomes at the level of basin council. Positive correlations significant at $\alpha=0.1$ are shown as grey squares with a ' + ' sign; negative correlations significant at $\alpha=0.1$ are shown as black squares with a '-' sign; white indicates a lack of significant correlation at $\alpha=0.1$. Solid black lines divide groups of independent and dependent variable proxies. For example, WV 3 (5th column from right) has two significant negative correlations with proxies of participation (PC4 and PC 5). Please see Appendix 1 for a complete list of questions and the means by which they were coded.

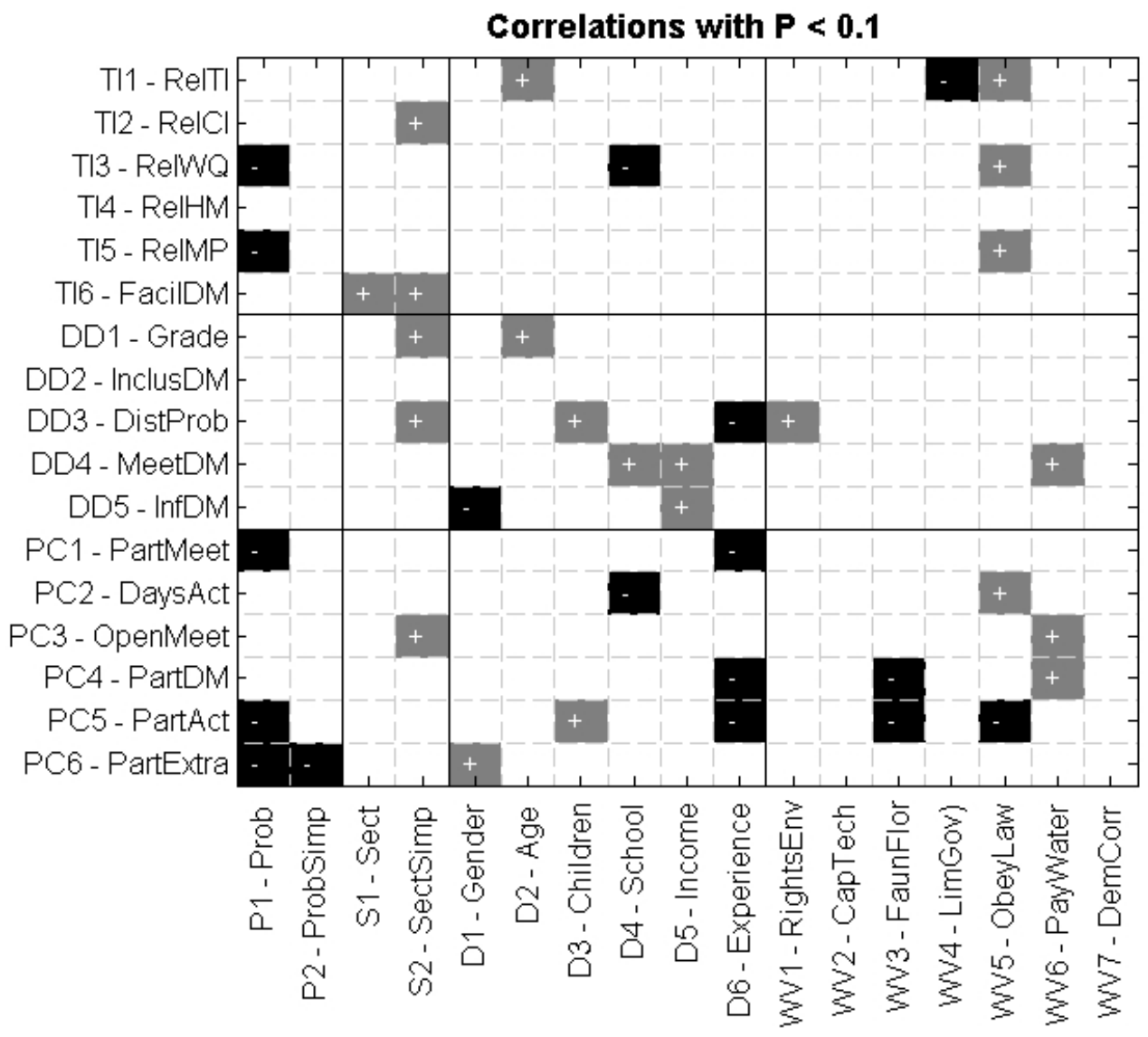

quality and broader environmental concerns, have been largely kept off the agenda (Formiga-Johnsson and Kemper 2005b).

\section{Diversity in sectoral representation}

We find that diversity in the sector represented by council members, i.e., users, public sector, and civil society (S1 and S2), correlates strongly (positively) with whether council members perceive the use of technical information as facilitating or making decision making more difficult (TI6). That is, within the basins studied in this project, the more diversity present in the council in terms of organizations and the sectors represented, the more council members perceive that technical information facilitates decision making. This perception reflects and supports findings of case study research that highlights the critical role that technical knowledge and experts, or técnicos as they are known in Brazil, have typically played in Brazil's water management 
and policy before and after the water reform. In the presence of diversity of interests, the advantage of using technical information is twofold. First, it is perceived as 'superior' to other forms of knowledge because of its origin in science. Second, it may be perceived as 'neutral' in relation to the many interests represented. In the Jaguaribe-Banabuiú and Paraíba do Sul basins for example, técnicos have historically influenced council decisions both through their dominance of technical information but also through their role as brokers of information and political power and as representatives of other socio-environmental interests (Lemos and Oliveira 2004, Kumler and Lemos 2008, Engle and Lemos 2010, Gutierrez 2010). However, although council members perceive that technical information facilitates decision making, they also perceive it as introducing inequality in the decision making environment (Abers et al. 2009). That is, in many basins a majority of council members perceive técnicos as the most powerful players in the basin (Lemos et al. 2010). Again in the example of the Jaguaribe-Banabuiú basin, this perception reflects the dominance of técnicos who couch their interests in sophisticated, technical language as a recurring rhetorical tactic to enhance the legitimacy of arguments and to insulate decision making (Lemos 2008, Taddei et al. 2004).

We also find that diversity of sectoral representation correlates positively with participation and perceived democratic decision making. This makes sense because members may be more willing to participate when they perceive that their interests would not otherwise be represented, or when they are fragmented across and in relation to a large number of other interests. These findings agree with the argument of Abers et al. (2009), that despite the different levels of access, resources, and policy influence held by different users, for example power generators and industry as compared to civil society organizations and smaller users groups, the councils are able to enhance their legitimacy by providing a forum for voices that otherwise would not be heard.

\section{Diversity in demographics}

Diversity in gender (D1) exhibits a mix of positive and negative correlations, i.e., a greater mix of men and women on the council seems to encourage participation, but acts as a barrier to the perception of democratic decision making. In our sample, the mean proportion of women on the council is 0.21
(S.D. 0.11), suggesting that for the councils we studied, women are generally underrepresented and less well-integrated. Less positive interactions among women in less integrated environments may help explain the negative correlation with perceived democratic decision making in our data. For example, in a study of diversity in the workplace, Ely (1994) found that women's behavior in groups differed depending on whether they were well integrated (even mixes of men and women, and the entropy maximum) or underrepresented, i.e., in well-integrated groups, women were more supportive of their peers and more positive toward other female members (Ely 1994).

Interestingly, diversity in age, experience, and education all relate to perceptions within the council in different ways. Diversity in age (D2) correlates positively with the perception of democratic decision making, and with the perceived relevance of technical information. This again may point toward the generally positive perception of technical knowledge to support decision making irrespective of its role as a source of inequity.

In contrast, diversity in the number of years working on water issues (D6) correlates negatively with reported participation, and with perceived democratic decision making. This finding paints a picture of councils divided along the lines of more or less experienced members where the former dominate the discussion and decision making process at the expense of the latter. In turn, less experienced members may feel discouraged to participate and perceive the process as less than democratic. It is also consistent with the related concept of organizational cohort effects (Tsui et al. 1992), which suggest that individuals entering into a group or field at the same time will share common values and experiences, and that diversity in the tenure that individuals have within a group may reduce the possibility for social integration (Milliken and Martins 1996). The finding is also supported by empirical work in the Tibagi Basin in Paraná, Brazil, where a history of minimal inclusion and experience of civil society organizations in the basin's decision making processes has fostered mistrust and limited participation in the council (Brannstrom et al. 2004). However, a lack of participation does not necessarily reflect a negative perception regarding the performance of the council; in some instances this perception seems to be informed by the belief that 'those who know better are addressing the issue.' In the Paraíba do 
Sul river basin committee, for example, special task forces formed primarily by experienced networks of técnicos have been entrusted with important decisions on behalf of the larger committee (Kumler and Lemos 2008). In other cases, council members have seen as positive the fact that many important council decisions are debated and prepared by smaller groups within the council before being presented to the council's general assembly (Lemos et al. 2010).

Diversity in the years of education (D4) is negatively correlated with participation and perceived importance of technical information, but positively correlated with perceived level of democratic decision making. Perhaps differences in education levels within the council have similar effects to differences in experience with water issues, but differ in the role they have on democratic decision making. That is, more education does not crystallize viewpoints and attitudes in the way that more experience with water issues does, making it possible to reach agreements democratically. However, differences in the level of education among members, that is, the differential capacity of members with higher or lower education to understand technical information, might still limit the role that technical information can play in facilitating discussion and the active participation of all members.

Possible roles for diversity in income (D5) and in the mix of parents in the council (D3) are less obvious. They perhaps serve as a reminder that we are still dealing with a small dataset and need to remain critical of the results that emerge.

\section{Diversity in worldviews}

Within the set of worldview questions, WV5 and WV6 exhibited the most interesting correlations with council processes. Use of knowledge correlated positively with diversity of perceptions within the councils of how people generally respond to laws (WV5), while showing a mixed relationship with participation. Also, disagreement about who should pay the most for water use, either those with the greatest ability to pay, or those who pollute or consume the most (WV6), is positively correlated with level of participation and perceived democratic decision making. Question WV6 has an underlying goal of understanding how water use can be rationalized while generating revenue in the process, so that diversity in WV6 reflects differences in opinion about how to do so and who to target, i.e., differences in the preferred instrument but not the fundamental preference (Page 2007). More generally, diversity in both WV5 and WV6 reflects differences in the perception of how better to provide incentives to people, differences in instrumental preferences that Page would predict lead to better outcomes for the councils.

\section{LIMITATIONS AND IMPLICATIONS}

A key limitation of our study is that it analyzes perceptions of the deliberative process, rather than the process itself. Although there is not an obvious reason for participants to misreport their experiences, their perceptions remain an indirect signal of what we are interested in and subject to recall errors as well as variability in the interpretation of questions across respondents, among other sources of error. Additionally, some of the unobserved characteristics from which we derive independent variables have potential to be influenced by the deliberative process and thus endogenously defined; while worldviews may reflect deep-seated values and be less malleable, perceptions of which are the most pressing problems in the basin may certainly be jointly defined both by life experience outside the council as well as through council deliberation and experience. The current study is an opportunistic use of an in-depth survey of basin council experience, but it demonstrates the value in deliberate fieldwork focused on diversity in basin councils. Observation of basin council deliberations around focusing events, such as droughts or allocation processes, controlling for how established the councils and their dynamics are, i.e., age of the council as a body and turnover rates for council membership, or controlled deliberations over hypothetical situations with the same groups, would provide a valuable lens into the way the deliberative process works in the Brazilian context.

Along this line, our study suggests a small number of hypotheses that may guide the design and implementation of such observation and experimental studies. First, diversity in the perception of what is the most important problem will impede the deliberative process, lessen participation, and lead to poorer outcomes; also, that diversity in these perceptions will be lower in more established councils, as participants learn from the deliberative 
process. Second, diversity in characteristics that tend to bring together different approaches to solving problems, such as sectoral representation, education, and experience, will lead to better outcomes of the deliberative processes. Finally, diversity in observable characteristics, such as sector, age, gender, etc., can be an indicator of the quality of deliberative outcomes within the council. This last hypothesis emerges as a test of whether observable characteristics, which will correlate with various unobservable characteristics, are valuable as design criteria for deliberative bodies. These among other hypotheses would help sharpen our understanding of the role of diversity in driving council performance, and improve our ability to structure councils and other bodies for natural resources governance.

\section{CONCLUSIONS}

Scholars and practitioners generally accept the notion that ecological and social diversity contribute positively to the structure and function of systems. Within institutions and management regimes, however, it is unclear how diversity of individuals and interests might affect particular aspects of the deliberative process. In this study, we find that different kinds of diversity matter in different ways. We investigate diversity in 18 Brazilian river basin councils and go beyond the concept of diversity as typically defined in water and natural resource management literature, i.e., sector of society that an individual represents, to also include diversity of demographic characteristics, worldviews and beliefs, and perception of core basin problems. We assume that each individual brings all of these aspects of diversity, and likely more, to the deliberative decision making process within the councils. In turn, such diversity influences participation, the perceived importance of technical information, and the perception of democracy within the committee.

We find that within the basins studied in this project, first, the more diversity in organizations and the sectors represented on the council, the more council members participate in council activities, perceive decision making to be democratic, and perceive technical information to facilitate decision making. Second, diversity in what members perceive to be the most pressing problems facing the basin and also diversity in worldviews often correlate negatively with some measures of participation and the perceived importance of technical knowledge. Third, within the demographic category, diversity in the years of experience in water issues correlates negatively with some measures of participation and perceived democratic decision making. However, a number of the other aspects of demographic diversity show a mix of positive and negative associations with the three process categories. Fourth, diversity in the perception of the most important problem facing the basin leads to poorer satisfaction in the council. On a more positive note, diversity in sectors represented on a council appears to lead to better perception of the decision making process and improved satisfaction in the council. This suggests that benefits from the different approaches to problem solving that people from different sectors bring to the council might outweigh fundamental differences in goals. This is an argument for supporting broad sectoral representation of interests within deliberative decision making bodies. Thus, decision makers might benefit from focusing on these areas where diversity correlates negatively with perception of the deliberative process to help remove barriers and ultimately improve deliberative decision making in Brazilian river basin councils.

Responses to this article can be read online at: http://www.ecologyandsociety.org/voll6/iss 1/art42/ responses/

\section{Acknowledgments:}

This research was made possible by NSF grant \# SES 0646347. We also would like to thank all the survey participants and key informants who have contributed to this project database.

\section{LITERATURE CITED}

Abers, R. N. 2007. Organizing for governance: building collaboration in Brazilian river basins. World Development 35:1450-1463.

Abers, R. N., and K. J. Dino. 2005. Descentralização da Gestão da gua: Por que os Comitês de Bacia Estão Sendo Criados? Ambiente e Sociedade 8:99-124. 
Abers, R. N., R. M. Formiga-Johnsson, B. Frank, M. E. Keck, and M. C. Lemos. 2009. Inclusão, deliberação e controle: três dimensões de democracia nos comitês e consórcios de bacia hidrográfica no Brasil. Ambiente e Sociedade 12:115-132.

Allen, C. R., L. Gunderson, and A. R. Johnson. 2005. The use of discontinuities and functional groups to assess relative resilience in complex systems. Ecosystems 8:958-966.

Brannstrom, C., J. Clarke, and M. Newport. 2004. Civil society participation in the decentralization of Brazil's water resources: assessing participation in three states. Singapore Journal of Tropical Geography 25:304-321.

Ely, R. J. 1994. The effects of organizational demographics and social identity on relationships among professional women. Administrative Science Quarterly 39:203-238.

Engle, N., and M. C. Lemos. 2010. Unpacking governance: building adaptive capacity to climate change for river basins in Brazil. Global Environmental Change 20:4-13.

Focht, W., and Z. Trachtenberg. 2005. A trust-based guide to stakeholder participation. Pages 85-135 in P. A. Sabatier, W. Focht, M. Lubell, Z. Trachtenberg, A. Vedlitz, and M. Matlock, editors. Swimming upstream: collaborative approaches to watershed management. MIT Press, Cambridge, Massachusetts, USA.

Formiga-Johnsson, R. M., and K. E. Kemper. 2005a. Institutional and policy analysis of river basin management - the Alto-Tietê River Basin, São Paulo, Brazil. Policy Research Working Paper Series, Number 3650, World Bank, Washington, D. C., USA.

Formiga-Johnsson, R. M., and K. E. Kemper. $2005 b$. Institutional and policy analysis of river basin management - the Jaguaribe River Basin, Ceará, Brazil. Policy Research Working Paper Series, Number 3649, World Bank, Washington, D. C., USA.

Gleick, P. H. 2000. The changing water paradigm: a look at twenty-first century water resources development. Water International 25:127-138.
Gutierrez, R. A. 2010. When experts do politics: introducing water policy reform in Brazil. Governance 23:59-88.

Koontz, T. M., and E. M. Johnson. 2004. One size does not fit all: matching breadth of stakeholder participation to watershed group accomplishments. Policy Sciences 37:185-204.

Kumler, L. M., and M. C. Lemos. 2008. Managing waters of the Paraíba do Sul river basin, Brazil: a case study in institutional change and social learning. Ecology and Society 13(2): 22. [online] URL: http://www.ecologyandsociety.org/vol13/iss2/ $\operatorname{art} 22 /$.

Leach, W. D. 2004. Is devolution democratic? Assessing collaborative environmental management. Center for Collaborative Policy, California State University, Sacramento, California, USA.

Lemos, M. C. 2008. Whose water is it anyway? Water management, knowledge, and equity in northeast Brazil. Pages 249-270 in J. Whiteley, H. Ingram, and R. W. Perry, editors. Water, Place, and Equity. MIT Press, Cambridge, Massachusetts, USA.

Lemos, M. C., and A. Agrawal. 2006. Environmental governance. Annual Review of Environment and Resources 31:297-325.

Lemos, M. C., A. Bell, N. Engle, R. M. FormigaJohnsson, and D. R. Nelson. 2010. Technical knowledge and water resources management: a comparative study of river basin councils, Brazil. Water Resources Research 46, W06523, doi:10.1029/2009WR007949.

Lemos, M. C., and J. L. F. Oliveira. 2004. Can water reform survive politics? Institutional change and river basin management in Ceará, northeast Brazil. World Development 32:2121-2137.

Lubell, M. 2005. Do watershed partnerships enhance beliefs conducive to collective action? Pages 201-231 in P. A. Sabatier, W. Focht, M. Lubell, Z. Trachtenberg, A. Vedlitz and M. Matlock, editors. Swimming upstream: collaborative approaches to watershed management. MIT Press, Cambridge, Massachusetts, USA.

Medema, W., B. S. McIntosh, and P. J. Jeffrey. 2008. From premise to practice: a critical 
assessment of integrated water resources management and adaptive management approaches in the water sector. Ecology and Society 13(2): 29. [online] URL: http://www.ecologyandsociety.org/voll3/ iss $2 / \operatorname{art} 29 /$.

Milliken, F. J., and L. L. Martins. 1996. Searching for common threads: understanding the multiple effects of diversity in organizational groups. Academy of Management Review 21:402-433.

Page, S. E. 2007. The difference: how the power of diversity creates better groups, firms, schools, and societies. Princeton University Press, Princeton, New Jersey, USA.

Peterson, G. D., C. R. Allen, and C. S. Holling. 1998. Ecological resilience, biodiversity and scale. Ecosystems 1:6-18.

Taddei, R., K. Broad, and A. Pfaff. 2004. Integrating climate and water management in Ceará: historical background, social and legal structures, and implications. In U. Lall and F. A. Souza Filho, editors. Gerenciamento Integrado dos Recursos Hídricos com Incorporação da Previsão Climática: da Informação e Previsão Climática à Redução das Vulnerabilidades às Secas no Semi-Árido Cearense, Volume 3. IRI/FUNCEME, Palisades, New York, USA and Fortaleza, Brazil.

Tsui, A. S., T. D. Egan, and C. A. Oreilly. 1992. Being different - relational demography and organizational attachment. Administrative Science Quarterly 37:549-579.

Velleman, P. F., and L. Wilkinson. 1993. Nominal, ordinal, interval, and ratio typologies are misleading. The American Statistician 47:65-72.

Wester, P., D. J. Merrey, and M. de Lange. 2003. Boundaries of consent: stakeholder representation in river basin management in Mexico and South Africa. World Development 31:797-812.

Wright, B. D., and J. M. Linacre. 1989. Observations are always ordinal; measurements, however, must be interval. Archives of Physical Medicine and Rehabilitation 70:857-860. 


\section{APPENDIX 1}

\section{Variable Descriptions}

Table A1 - Dependent Variables

\begin{tabular}{|c|c|c|}
\hline $\begin{array}{l}\text { Code - } \\
\text { Short } \\
\text { Name }\end{array}$ & Full Question & Coding \\
\hline $\begin{array}{l}\text { TI1 - } \\
\text { RelTI }\end{array}$ & $\begin{array}{l}\text { On a scale where } 0 \text { means irrelevant and } 10 \text { means highly relevant, } \\
\text { how much importance would you attribute to the use of technical } \\
\text { information for water resource management in the basin? }\end{array}$ & Mean response across council \\
\hline $\begin{array}{l}\text { TI2 - } \\
\text { RelCI }\end{array}$ & $\begin{array}{l}\text { For climate information (médium and long term predictions, for } \\
\text { example predictions of drought, or of El Niño), how relevant is this } \\
\text { kind of information for solving the basin's problems? }\end{array}$ & Mean response across council \\
\hline $\begin{array}{l}\text { TI3 - } \\
\text { RelWQ }\end{array}$ & And information about water quality? & Mean response across council \\
\hline $\begin{array}{l}\text { TI4 - } \\
\text { RelHM }\end{array}$ & $\begin{array}{l}\text { And hydrological models (for example, studies of water availability)? } \\
\text { How relevant are these for solving the basin's problems? }\end{array}$ & Mean response across council \\
\hline $\begin{array}{l}\text { TI5 - } \\
\text { RelMP }\end{array}$ & And management and planning studies? & Mean response across council \\
\hline $\begin{array}{l}\text { TI6 - } \\
\text { FacilDM }\end{array}$ & $\begin{array}{l}\text { Generally speaking, in your experience on the committee, does } \\
\text { technical information 1) facilitate decision-making, since it helps us } \\
\text { understand the problems, or } 2 \text { ) make decision-making more difficult, } \\
\text { because complicated or because of conflicting assessments? }\end{array}$ & $\begin{array}{l}\text { Proportion of council members } \\
\text { answering ' } 1 \text { ' }\end{array}$ \\
\hline $\begin{array}{l}\text { DD1 - } \\
\text { Grade }\end{array}$ & $\begin{array}{l}\text { And regarding how democratically decisions are made, what grade } \\
\text { would you give it? }\end{array}$ & Mean response across council \\
\hline $\begin{array}{l}\mathrm{DD} 2- \\
\text { InclusD } \\
\mathrm{M}\end{array}$ & $\begin{array}{l}\text { With regard to how the committee members participate in defining } \\
\text { the organ's activities, which of the following are closest to your } \\
\text { opinion? The activities of this organization are defined 1) By all the } \\
\text { members who want to be involved in these decisions 2) By a small } \\
\text { group, but one that values the contributions of all the members 3) By } \\
\text { a small group, which does not always discuss these decisions with } \\
\text { other members }\end{array}$ & $\begin{array}{l}\text { Mean response across council } \\
\text { where ' } 1 \text { ' is assigned a score } \\
\text { of } 1, \text { ' } 2 \text { ' a score of } 0.5 \text {, and ' } 3 \text { ' } \\
\text { a score of } 0\end{array}$ \\
\hline $\begin{array}{l}\text { DD3 - } \\
\text { DistProb }\end{array}$ & $\begin{array}{l}\text { In some committees, there are distinctions among members which can } \\
\text { make a democratic decision-making process difficult. In your views, } \\
\text { Which of these distinctions have gotten in the way of democracy in } \\
\text { your committee? A) Unequal technical knowledge among members } \\
\text { B) Unequal economic power among members C) Unequal political } \\
\text { power among members }\end{array}$ & $\begin{array}{l}\text { Mean response across council } \\
\text { members where a score of } 1 \text { is } \\
\text { given to each of 'A', 'B', and } \\
\text { ' } \mathrm{C} \text { ', for a potential score of } 3\end{array}$ \\
\hline $\begin{array}{l}\text { DD4 - } \\
\text { MeetDM }\end{array}$ & $\begin{array}{l}\text { In your opinion 1) Most decisions are negotiated before the plenary } \\
\text { meeting takes place, or 2) Most decisions are negotiated during the } \\
\text { plenary meetings. }\end{array}$ & $\begin{array}{l}\text { Proportion of council members } \\
\text { responding ' } 2 \text { ' }\end{array}$ \\
\hline $\begin{array}{l}\text { DD5 - } \\
\text { InfDM }\end{array}$ & $\begin{array}{l}\text { Still on the decision making process, which of these sectors or } \\
\text { levels of the committee, in your view, has the most influence over } \\
\text { decisions made at plenary meetings?1) The officers 2) Technical } \\
\text { subcommittees 3) Executive secretary/ Structure of technical \& } \\
\text { organizational support/Basin Agency 4) Users in the sanitation } \\
\text { sector 5) Users in the productive sector (industry, electrical } \\
\text { energy, mining, etc.) 6) Environmental groups 7) Universities or }\end{array}$ & $\begin{array}{l}\text { Entropy of responses across } \\
\text { council (where high entropy } \\
\text { would be a signal that no } \\
\text { particular group stood out as } \\
\text { the most influential) }\end{array}$ \\
\hline
\end{tabular}




\begin{tabular}{|c|c|c|}
\hline & $\begin{array}{l}\text { technical associations 8) Other civil society groups 9) Federal } \\
\text { government 10) State government 11) Municipal government }\end{array}$ & \\
\hline $\begin{array}{l}\text { PC1 - } \\
\text { PartMeet }\end{array}$ & $\begin{array}{l}\text { Now I would like you to assess your involvement in this committee, } \\
\text { telling us how often you participate in different activities - a majority } \\
\text { of plenary meetings, a few meetings, or none? A) Attend B) Speak in } \\
\text { C) Present proposals in }\end{array}$ & $\begin{array}{l}\text { Mean response across council } \\
\text { members where for each of } \\
\text { 'A','B', and 'C', a score of } 1 \\
\text { is given to 'majority of plenary } \\
\text { meetings', } 0.5 \text { is given to 'a } \\
\text { few meetings', and } 0 \text { is given } \\
\text { to 'none', for a potential total } \\
\text { score of } 3\end{array}$ \\
\hline $\begin{array}{l}\mathrm{PC} 2- \\
\text { DaysAct }\end{array}$ & $\begin{array}{l}\text { How many days per month, on average, do you spend on this } \\
\text { committee's activities, outside of the plenary meetings? }\end{array}$ & Mean response across council \\
\hline $\begin{array}{l}\text { PC3 - } \\
\text { OpenMee } \\
\text { t }\end{array}$ & $\begin{array}{l}\text { In your opinion, do people feel comfortable about expressing } \\
\text { themselves freely when they discuss their concerns and proposals in } \\
\text { the committee? }\end{array}$ & $\begin{array}{l}\text { Proportion of council members } \\
\text { responding 'Yes' }\end{array}$ \\
\hline $\begin{array}{l}\text { PC4 - } \\
\text { PartDM }\end{array}$ & $\begin{array}{l}\text { Do you take part in these negotiations? (referring to negotiations } \\
\text { where committee decision are made) }\end{array}$ & $\begin{array}{l}\text { Proportion of council members } \\
\text { responding 'Yes' }\end{array}$ \\
\hline $\begin{array}{l}\text { PC5 - } \\
\text { PartAct }\end{array}$ & $\begin{array}{l}\text { I would like you to tell me what you do in relation to the committee's } \\
\text { activities in addition to the plenary meetings, telling us how often you } \\
\text { A) Take part in Working Groups or technical subcommittees? B) } \\
\text { Organize events and seminars? C) Collaborate with other members on } \\
\text { specific projects? D) Facilitate negotiation among members? E) Write } \\
\text { documents or technical reports? F) Represent the committee in other } \\
\text { forums? G) Raise money and materials for committee activities? }\end{array}$ & $\begin{array}{l}\text { Mean response across council } \\
\text { members where for each of } \\
\text { 'A' through ' } G \text { ', a score of } 1 \text { is } \\
\text { given to 'often', } 0.5 \text { is given to } \\
\text { 'rarely', and } 0 \text { is given to } \\
\text { 'never, for a potential total } \\
\text { score of } 7\end{array}$ \\
\hline $\begin{array}{l}\text { PC6 - } \\
\text { PartExtra }\end{array}$ & $\begin{array}{l}\text { In the last month, have you participated in any event related to water } \\
\text { resources besides those activities sponsored by the committee? }\end{array}$ & $\begin{array}{l}\text { Proportion of council members } \\
\text { responding 'Yes' }\end{array}$ \\
\hline
\end{tabular}

Table A2 - Independent Variables

\begin{tabular}{|c|c|c|}
\hline $\begin{array}{l}\text { Code - } \\
\text { Short } \\
\text { Name }\end{array}$ & Full Question & Coding \\
\hline $\begin{array}{l}\text { WV1- } \\
\text { RightsEn } \\
\text { V }\end{array}$ & $\begin{array}{l}\text { Now I am going to read a series of statements and I } \\
\text { would like to know whether you agree or disagree } \\
\text { with each of them. "Human beings have the right to } \\
\text { change and use the environment to satisfy their } \\
\text { needs." }\end{array}$ & $\begin{array}{l}\text { Standard deviation across council among } \\
\text { responses with 'strongly agree' coded as } 1 \text {, } \\
\text { 'agree' as } 0.66 \text {, 'disagree' as } 0.33 \text {, and 'strongly } \\
\text { disagree' as } 0\end{array}$ \\
\hline $\begin{array}{l}\text { WV2 - } \\
\text { CapTech }\end{array}$ & $\begin{array}{l}\text { The ability of human beings to invent new } \\
\text { technology will always guarantee the existence of } \\
\text { life on the planet. }\end{array}$ & $\begin{array}{l}\text { Standard deviation across council among } \\
\text { responses with 'strongly agree' coded as } 1 \text {, } \\
\text { 'agree' as } 0.66 \text {, 'disagree' as } 0.33 \text {, and 'strongly } \\
\text { disagree' as } 0\end{array}$ \\
\hline $\begin{array}{l}\text { WV3- } \\
\text { FaunFlor }\end{array}$ & $\begin{array}{l}\text { Plants and animals have as much right to exist as } \\
\text { people do. }\end{array}$ & $\begin{array}{l}\text { Standard deviation across council among } \\
\text { responses with 'strongly agree' coded as } 1 \text {, } \\
\text { 'agree' as } 0.66 \text {, 'disagree' as } 0.33 \text {, and 'strongly } \\
\text { disagree' as } 0\end{array}$ \\
\hline $\begin{array}{l}\text { WV4 - } \\
\text { LimGov }\end{array}$ & $\begin{array}{l}\text { Which of these statements comes closest to your } \\
\text { point of view? 1) To defend the common interests } \\
\text { of society, the government has to place limits on the } \\
\text { use of natural resources on private property, or 2) }\end{array}$ & Entropy across council responses of ' 1 ' and ' 2 ' \\
\hline
\end{tabular}




\begin{tabular}{|c|c|c|}
\hline & $\begin{array}{l}\text { Landowners have the right to use the natural } \\
\text { resources on their properties as they see fit. }\end{array}$ & \\
\hline $\begin{array}{l}\text { WV5 - } \\
\text { ObeyLaw }\end{array}$ & $\begin{array}{l}\text { Generally speaking, do you think that people } \\
\text { usually obey the law, even when it would be more } \\
\text { convenient not to do so? }\end{array}$ & $\begin{array}{l}\text { Entropy across council responses of 'Yes' and } \\
\text { 'No' }\end{array}$ \\
\hline $\begin{array}{l}\text { WV6- } \\
\text { PayWater }\end{array}$ & $\begin{array}{l}\text { And who should pay the most (regarding water } \\
\text { users paying for consumption)? 1) Whoever } \\
\text { pollutes or consumes the most, irregardless of the } \\
\text { sector, or 2) whoever has the greatest economic } \\
\text { and/or financial ability to pay. }\end{array}$ & Entropy across council responses of ' 1 ' and ' 2 ' \\
\hline $\begin{array}{l}\text { WV7 - } \\
\text { DemCorr }\end{array}$ & $\begin{array}{l}\text { For our research, we think it is important to } \\
\text { understand how people behave when they have } \\
\text { difficult choices to make. For example, in a } \\
\text { decision-making process, if you had to choose } \\
\text { between the following options, which one would } \\
\text { you in principle consider the most important? 1) } \\
\text { That decisions be made in a democratic manner, or } \\
\text { 2) that the decisions be technically correct. }\end{array}$ & Entropy across council responses of ' 1 ' and ' 2 ' \\
\hline P1 - Prob & $\begin{array}{l}\text { In your opinion, what is the main water related } \\
\text { problem in your basin? }\end{array}$ & $\begin{array}{l}\text { Entropy across council responses of } \\
\text { 'Agricultural Pollution', 'Urban Pollution', } \\
\text { 'Environmental Pollution', 'Industrial Pollution', } \\
\text { 'Drought', 'Flood', 'Government', 'Excessive } \\
\text { Use', 'Other', 'No Problem' }\end{array}$ \\
\hline $\begin{array}{l}\text { P2- } \\
\text { ProbSim } \\
\text { p }\end{array}$ & $\begin{array}{l}\text { In your opinion, what is the main water related } \\
\text { problem in your basin? }\end{array}$ & $\begin{array}{l}\text { Entropy across council responses as above, but } \\
\text { aggregated to 'Pollution', 'Excessive Use and } \\
\text { Drought', and 'Other Problems' }\end{array}$ \\
\hline $\mathrm{S} 1-\mathrm{Sect}$ & To what sector does your organization belong? & $\begin{array}{l}\text { Entropy across council responses of 'Basic } \\
\text { sanitation', 'Energy production', 'Industry', } \\
\text { 'Irrigated agriculture', 'Non-irrigated } \\
\text { agriculture', 'Mining', 'Ranching', 'Fishing', } \\
\text { 'Fish or shrimp farming', } \\
\text { 'Transportation/Navigation', 'Tourism/Leisure', } \\
\text { or 'Another sector not on this list' }\end{array}$ \\
\hline $\begin{array}{l}\text { S2- } \\
\text { SectSimp }\end{array}$ & $\begin{array}{l}\text { To what category does the organization you } \\
\text { represent on the committee belong? }\end{array}$ & $\begin{array}{l}\text { Entropy across council responses of 'Users', } \\
\text { 'Public Sector', or 'Civil Society' }\end{array}$ \\
\hline $\begin{array}{l}\text { D1 - } \\
\text { Gender }\end{array}$ & Sex (not asked) & $\begin{array}{l}\text { Entropy across observed council make-up of } \\
\text { men and women }\end{array}$ \\
\hline D2 - Age & How old are you? & Standard deviation across council responses \\
\hline $\begin{array}{l}\text { D3- } \\
\text { Children }\end{array}$ & Do you have children? & $\begin{array}{l}\text { Entropy across council responses of 'Yes' and } \\
\text { 'No' }\end{array}$ \\
\hline $\begin{array}{l}\text { D4 - } \\
\text { School }\end{array}$ & How far did you go in school? & $\begin{array}{l}\text { Standard deviation across council responses of } \\
\text { number of years of education }\end{array}$ \\
\hline $\begin{array}{l}\text { D5 - } \\
\text { Income }\end{array}$ & $\begin{array}{l}\text { Could you indicate for us please your total monthly } \\
\text { household income, adding up all your income, } \\
\text { wages, rents, etc., over the last month? }\end{array}$ & $\begin{array}{l}\text { Standard deviation across council responses of } \\
\text { annual income }\end{array}$ \\
\hline $\begin{array}{l}\text { D6- } \\
\text { Experien } \\
\text { ce }\end{array}$ & $\begin{array}{l}\text { How long have you worked on water issues, } \\
\text { including the time you were studying, professional } \\
\text { or volunteer activities, and / or as a member of the } \\
\text { committee? }\end{array}$ & $\begin{array}{l}\text { Standard deviation across council responses of } \\
\text { number of years of experience }\end{array}$ \\
\hline
\end{tabular}




\section{APPENDIX 2}

\section{Correlation Data}

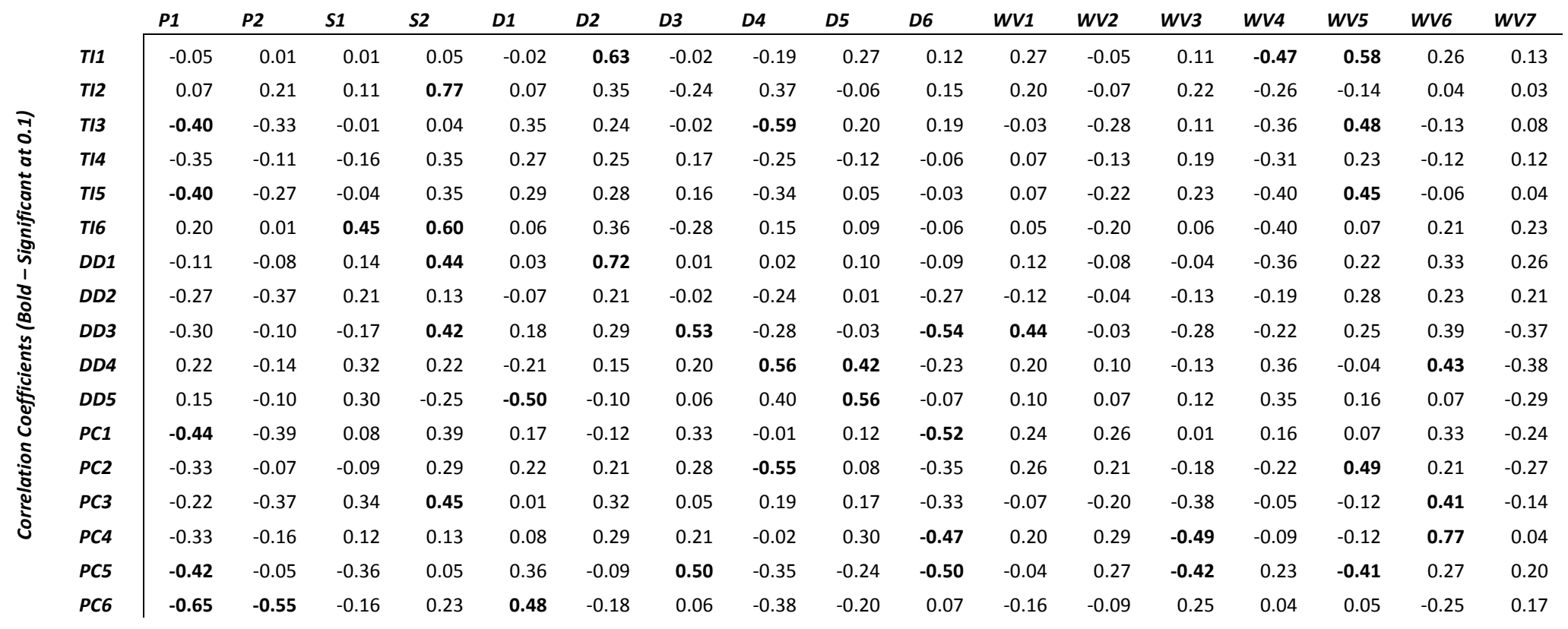




\begin{tabular}{|c|c|c|c|c|c|c|c|c|c|c|c|c|c|c|c|c|c|}
\hline & $P 1$ & $P 2$ & $s 1$ & $S 2$ & $D 1$ & $D 2$ & D3 & $D 4$ & D5 & $D 6$ & $w V 1$ & WV2 & wV3 & WV4 & wV5 & wV6 & $w V 7$ \\
\hline TI1 & 0.85 & 0.98 & 0.96 & 0.84 & 0.93 & 0.00 & 0.94 & 0.46 & 0.28 & 0.64 & 0.27 & 0.84 & 0.66 & 0.05 & 0.01 & 0.29 & 0.61 \\
\hline$T 12$ & 0.79 & 0.40 & 0.66 & 0.00 & 0.77 & 0.15 & 0.33 & 0.13 & 0.82 & 0.56 & 0.43 & 0.78 & 0.38 & 0.29 & 0.58 & 0.88 & 0.90 \\
\hline$T / 3$ & 0.10 & 0.18 & 0.98 & 0.87 & 0.16 & 0.33 & 0.92 & 0.01 & 0.43 & 0.46 & 0.90 & 0.26 & 0.67 & 0.15 & 0.04 & 0.62 & 0.76 \\
\hline$T 14$ & 0.16 & 0.68 & 0.51 & 0.15 & 0.28 & 0.32 & 0.49 & 0.31 & 0.64 & 0.81 & 0.78 & 0.61 & 0.45 & 0.22 & 0.35 & 0.65 & 0.63 \\
\hline T15 & 0.10 & 0.28 & 0.88 & 0.15 & 0.25 & 0.26 & 0.53 & 0.16 & 0.85 & 0.91 & 0.77 & 0.38 & 0.35 & 0.10 & 0.06 & 0.81 & 0.87 \\
\hline T16 & 0.42 & 0.95 & 0.06 & 0.01 & 0.80 & 0.14 & 0.25 & 0.56 & 0.71 & 0.81 & 0.83 & 0.42 & 0.80 & 0.10 & 0.79 & 0.41 & 0.37 \\
\hline$D D 1$ & 0.67 & 0.75 & 0.59 & 0.07 & 0.91 & 0.00 & 0.98 & 0.94 & 0.70 & 0.72 & 0.64 & 0.74 & 0.86 & 0.15 & 0.39 & 0.18 & 0.29 \\
\hline$D D 2$ & 0.28 & 0.13 & 0.40 & 0.62 & 0.79 & 0.41 & 0.94 & 0.34 & 0.97 & 0.29 & 0.63 & 0.88 & 0.60 & 0.45 & 0.26 & 0.37 & 0.41 \\
\hline DD3 & 0.23 & 0.70 & 0.51 & 0.08 & 0.47 & 0.24 & 0.02 & 0.27 & 0.91 & 0.02 & 0.07 & 0.89 & 0.26 & 0.38 & 0.31 & 0.11 & 0.13 \\
\hline DD4 & 0.39 & 0.59 & 0.20 & 0.38 & 0.41 & 0.56 & 0.42 & 0.02 & 0.08 & 0.35 & 0.44 & 0.70 & 0.60 & 0.14 & 0.89 & 0.08 & 0.12 \\
\hline DD5 & 0.55 & 0.69 & 0.22 & 0.31 & 0.03 & 0.70 & 0.82 & 0.10 & 0.01 & 0.77 & 0.70 & 0.79 & 0.64 & 0.15 & 0.53 & 0.77 & 0.24 \\
\hline$P C 1$ & 0.06 & 0.11 & 0.76 & 0.11 & 0.51 & 0.65 & 0.19 & 0.95 & 0.63 & 0.03 & 0.33 & 0.30 & 0.96 & 0.54 & 0.79 & 0.18 & 0.34 \\
\hline$P C 2$ & 0.19 & 0.79 & 0.71 & 0.25 & 0.37 & 0.41 & 0.27 & 0.02 & 0.75 & 0.15 & 0.29 & 0.39 & 0.49 & 0.38 & 0.04 & 0.40 & 0.28 \\
\hline PC3 & 0.38 & 0.13 & 0.16 & 0.06 & 0.98 & 0.20 & 0.84 & 0.46 & 0.49 & 0.17 & 0.78 & 0.43 & 0.12 & 0.85 & 0.64 & 0.09 & 0.59 \\
\hline PC4 & 0.17 & 0.51 & 0.63 & 0.61 & 0.77 & 0.25 & 0.41 & 0.94 & 0.22 & 0.05 & 0.42 & 0.24 & 0.04 & 0.73 & 0.64 & 0.00 & 0.88 \\
\hline PC5 & 0.08 & 0.84 & 0.14 & 0.85 & 0.14 & 0.73 & 0.04 & 0.15 & 0.34 & 0.04 & 0.86 & 0.29 & 0.08 & 0.37 & 0.09 & 0.28 & 0.43 \\
\hline PC6 & 0.00 & 0.02 & 0.52 & 0.35 & 0.04 & 0.47 & 0.80 & 0.12 & 0.42 & 0.78 & 0.53 & 0.72 & 0.32 & 0.88 & 0.85 & 0.32 & 0.51 \\
\hline
\end{tabular}




\section{APPENDIX 3}

\section{Quantifying Diversity and Outcomes at the Basin Council Level}

Where we are interested in the simple 'magnitude' of response - how relevant technical information is perceived to be within a council, or how many council members feel that decisions are made democratically, we aggregate using mean or proportion. Questions with cardinal scale responses (e.g, 0 to 10, etc.) or ordinal responses (e.g., strongly agree to strongly disagree) are aggregated using the mean value across each basin. Ordinal responses are first transformed to cardinal responses by assuming their values to be evenly spaced between 0 and 1 . Thus, for example, the set ['often', 'sometimes', 'rarely', 'never'] becomes $[1,0.66,0.33,0]$. Transforming the data makes it more amenable to analysis, revealing information that might be lost by using the median (Wright and Linacre 1989, Velleman and Wilkinson 1993). Questions with yes or no responses, or where we are interested in a particular response (i.e., those that respond ' $b$ ', or those that respond ' 1 ' or ' 2 ') were aggregated using the proportion of council members giving the response of interest across each basin. We use these two modes of aggregation, mean and proportion, for all dependent variable proxies (with one exception, DD5 - see Appendix 1) to express the magnitude of perceived relevance of technical information, the magnitude of democratic decision-making, and the magnitude of participation in council activities (i.e., the dependent variables).

Where we are interested in the diversity of a response - how variable the response is within the council - we aggregate using standard deviation or entropy. Entropy and standard deviation are more sophisticated than the simple mean and proportion calculations and warrant further explanation. The standard deviation of an aggregate response within a given basin is calculated as:

$$
S D_{x}=\sqrt{\frac{1}{n_{c}} \sum_{1}^{n_{c}}\left(x_{i}-\bar{x}\right)^{2}}
$$

where $\mathrm{n}_{\mathrm{c}}$ is the number of responses in the basin. The standard deviation is a useful measure of variability when there is correlation among response options (e.g., a response of 5 is more similar to a response of 4 than would be a response of 8 ). When there is no correlation among response options (e.g., a respondent must select whether they represent a) a water user b) a government organ or c) a civil society organization), the use of a standard deviation is inappropriate. As a complement to the standard deviation for questions with uncorrelated response options, we calculate the entropy:

$$
E_{x}=\sum_{i}^{m_{x}}-p_{x=i} \cdot \ln \left(p_{x=i}\right)
$$


where $m_{x}$ is the number of response options and $p_{x=I}$ is the proportion of responses with response option $i$. With origins in the study of thermodynamics and a wide application in the study of material processes (Rechberger 2001, Rechberger and Graedel 2002, Kaufman et al. 2008), entropy, as calculated above, has found a place in social research fields in recent decades as a measure of uncertainty (Bailey 1983, Gill 2005), of flexibility (Shuiabi et al. 2005), of inequality (Allison 1978), and of diversity (Galtung 1980). This last application is the closest to our own usage of statistical entropy as a signal of diversity within uncorrelated response options.

Mathematically, the standard deviation and the entropy are not identical, but they share some characteristics that let them serve similar functions for ordinal/cardinal responses and for uncorrelated responses, respectively, in our analysis. Take for instance a question that asks a respondent to rate something on a scale from 1 to 5 (correlated and ordinal), and another question that asks a respondent to choose a response from a to e (uncorrelated). Both the standard deviation and the entropy are minimized when all respondents make the same response (i.e., all ' 3 ' or all 'e'). The standard deviation for the former is maximized when responses are evenly divided among the extremes (half ' 1 ' and half ' 5 '). The entropy for the latter is different (since there are no 'extreme' values when the response options are uncorrelated) and is maximized when responses are evenly distributed across all options (an even number of 'a', 'b', 'c', 'd', and 'e' responses). However, these two functions share the property that they generally increase from a minimum as responses grow more different, and thus allow for some comparison across ordinal/cardinal and uncorrelated response options where previously no comparison was possible.

We aggregate all proxies for the independent variables (as well as a single question in the make up of one of the dependent variables, DD) using the complementary relationships of entropy and standard deviation to express diversity in worldviews within the council, sector represented, perceived problems in the basin, and in demographic makeup. In the case of the one dependent variable proxy aggregated using entropy, we treat differences in the perception of who the most influential actor in the basin is as a signal of power sharing and thus of the magnitude of democratic decision-making in the basin.

We have chosen not to collapse our dependent or independent variable proxies into a single measure, as each variable represents a complex concept only partially revealed by each individual question, and response patterns to each question may be different. While a single index might be a useful tool for comparing different basins across a particular variable, it masks correlations that might exist between different responses, and is thus not useful for the purposes of this analysis. Instead, we look at the existence (or not) of significant correlations between particular aspects (i.e., the selected aggregate responses) of the dependent and independent variables, to gain a more general understanding of the relative roles $\mathrm{WV}, \mathrm{P}, \mathrm{S}$, and D play in explaining TI, DD, and $\mathrm{PC}$. 


\section{REFERENCES}

Allison, P. D. 1978. Measures Of Inequality. American Sociological Review 43:865-880.

Bailey, K. D. 1983. Sociological entropy theory - toward a statistical and verbal congruence. Quality \& Quantity 18:113-133.

Galtung, J. 1980. The true worlds : a transnational perspective. Free Press, New York.

Gill, J. 2005. An entropy measure of uncertainty in vote choice. Electoral Studies 24:371392.

Kaufman, S., E. Kwon, N. Krishnan, M. Castaldi and N. Themelis. 2008. Use of Statistical Entropy and Life Cycle Analysis to Evaluate Global Warming Potential of Waste Management Systems. 16th Annual North American Waster to Energy Conference Nawtec16 107-112.

Rechberger, H. 2001. The use of statistical entropy to evaluate the utilisation of incinerator ashes for the production of cement. Waste Management \& Research 19:262268.

Rechberger, H. and T. E. Graedel. 2002. The contemporary European copper cycle: statistical entropy analysis. Ecological Economics 42:59-72.

Shuiabi, E., V. Thomson and N. Bhuiyan. 2005. Entropy as a measure of operational flexibility. European Journal of Operational Research 165:696-707.

Velleman, P. F. and L. Wilkinson. 1993. Nominal, Ordinal, Inverval, and Ratio Typologies are Misleading. The American Statistician 47:65-72.

Wright, B. D. and J. M. Linacre. 1989. Observations are always ordinal; Measurements, however, must be interval. Archives of Physical Medicine and Rehabilitation 70:857-860. 